\title{
Implementasi Viewboard Berbasis Interaktif Javascript Charts Pada Sistem Penilaian Perkuliahan
}

\author{
${ }^{1}$ Untung Rahardja, ${ }^{2}$ Qurotul Aini, ${ }^{3}$ Fitri Faradilla \\ ${ }_{1,2,3}$ STMIK Raharja Tangerang \\ untung@raharja.info ${ }^{1)}$ aini@raharja.info ${ }^{2}$ fitri.faradilla@raharja.info ${ }^{3)}$
}

\begin{abstract}
ABSTRAK.Dalam penyajian informasi yang efektif dan efisien, diperlukan sebuah media yang dapat menampilkan informasi dengan ringkas sehingga dapat dengan mudah untuk dimengerti. Informasi hasil penilaian ujian pada Perguruan Tinggi Raharja kini dapat dengan mudah diakses oleh dosen pengampu mata kuliah, kepala jurusan dan mahasiswa melalui Pen+ (Penilaian Plus). Namun proses penyajian informasi dengan Pen+ (Penilaian Plus) masih menggunakan tabel, sehingga kurang sesuai dengan kemajuan teknologi saat ini. Dalam karya ilmiah ini, akan dijelaskan mengenai metode dengan 7 (tujuh) langkah yang digunakan untuk mengatasi 5 (lima) permasalahan, serta 2 (dua) solusi yaitu diterapkannya grafik Highcharts dan Google Charts. Keunggulan dari Pen+ (Penilaian Plus) adalah dapat diakses melalui website ataupun mobile, serta terdapat juga keunggulan lainnya yaitu mengurangi penggunaan kertas sehingga dapat membantu pekerjaan dosen dalam melakukan penilaian. Maka dapat disimpulkan bahwa penggunaan grafik Highcharts dan Google Charts mampu meningkatkan mutu dan mengatasi permasalahan yang terdapat dalam Pen+ (Penilaian Plus).
\end{abstract} Kata Kunci: Pen+ (Penilaian Plus); Grafik; Viewboard

ABSTRACT.In the presentation of information which are effective and efficient, it is required a media that can display the information in a way that can be easily understood. The information of examination results in Perguruan Tinggi Raharja are now can be easily accessed by lecturers, heads of majors and students through Pen+ (Penilaian Plus). However, the process of providing information in Pen+ (Penilaian Plus) is still using tables, making it less in accordance with the current technological advances. In this paper, there will be a method with 7 (seven) steps used to overcome 5 (five) problems, and 2 (two) solutions by applying Highcharts and Google Charts. The advantages of Pen+ (Penilaian Plus) is it can be accessed via website or mobile, and there are others advantages as which to reduce the usage of paper, so it can assist the lecuter's work in doing the assessment. Then it can be concluded, the use of Highcharts and Google Charts can improve the quality and overcome the problems in Pen+ (Penilaian Plus).

Keywords: Pen+ (Penilaian Plus); Charts; Viewboard

\section{PENDAHULUAN}

Dewasa ini informasi yang cepat dan tepat diperlukan untuk mendukung aktivitas kehidupan. Penyampaian informasi yang dari zaman ke zaman selalu berkembang menciptakan pengaruh besar kepada para penerima informasi(Kuntoro, 1978). Model dan sistem yang digunakan juga akan menentukan seberapa efektif dan baiknya proses penyampaian informasi yang berjalan. Kini informasi sudah tidak lagi diserap dengan mengandalkan alat-alat yang masih kuno dan konvensional, karenanya peran komputer menjadi sangat krusial dalam memberikan solusi untuk memecahkan masalah, selain itu komputer juga merupakan alat bantu yang sangat baik untuk mengembangkan sistem yang masih ketinggalan zaman (Rahardja, 2014).

Pada era globalisasi saat ini, setiap perguruan tinggi yang ada dituntut untuk dapat bersaing secara global, dan salah satu kunci keberhasilan dari persaingan global terletak pada bagaimana perguruan tinggi dapat memberikan pelayanan yang efisien dan cepat kepada mahasiswa (Warsito, 2014). Pelayanan yang diberikan secara efektif akan meningkatkan proses pembelajaran yang terjadi pada perguruan tinggi, serta dapat memperbaiki sistem pembelajaran yang telah diterapkan(Untung, 2012).

Perguruan Tinggi Raharja adalah perguruan tinggi yang senantiasa mengikuti perkembangan zaman yang bergerak dalam bidang ilmu teknologi dan informasi. Metode pembelajaran iLearning (Integrated Learning) yang diterapkan pada Perguruan Tinggi Raharja menciptakan proses pembelajaran yang efektif, tidak hanya belajar mengikuti arahan dari dosen namun juga mengajak mahasiswa untuk bekerja, bermain serta berdoa (Rahardja, 2014). Selain itu, metode pembelajaran iLearning juga menyediakan kemudahan bagi mahasiswa dan dosen dalam mengetahui informasi mengenai penilaian.

Kegiatan penilaian yang berjalan pada Perguruan Tinggi Raharja dilakukan untuk menilai dan mengukur tingkat pencapaian mahasiswa dalam memahami apa yang diajarkan. Selain itu penilaian juga digunakan sebagai alat untuk mengetahui kelebihan dan kelemahan pada proses pembelajaran (Sari, 2017). Perekapan nilai ujian yang saat ini masih menggunakan media manual seperti kertas dan alat tulis tidaklah 
seirama dengan perkembangan zaman. Demi tersampaikannya informasi penilaian dengan baik, dosen harus memiliki sebuah media penyampai informasi yang tepat. Penggunaan cara yang konvensional dalam proses penilaian harus diubah dengan cara lain yang lebih canggih, sehingga informasi yang disajikan dapat lebih mudah dipahami oleh mahasiswa yang ingin mencari tahu perihal informasi nilai ujian. Pen+ (Penilaian Plus) merupakan sistem penilaian online berbasis web dan mobile yang dapat diakses dimana saja dan kapan saja dengan tingkat keamanan sistem yang teruji, sehingga meningkatkan efisiensi bagi Perguruan Tinggi Raharja (Aini, 2016). Dengan digunakannya sistem Pen+ (Penilaian Plus), menyebabkan proses penilaian yang konvensional dengan menggunakan media kertas berkurang drastis. Permasalahan padamedia kertas yaitu bisa hilang dan rusak, menyebabkan data nilai ujian yang akan diberitahukan kepada mahasiswa tersampaikan dengan terlambat. Akibatnya dapat mengurangi kinerja dosen dikarenakan dosen seharusnya menyampaikan hasil ujian kepada mahasiswa dengan tepat waktu (Rahardja, 2017). Bahkan proses pembelajaran juga menjadi tertunda dikarenakan terlambatnya proses penyampaian informasi nilai ujian.

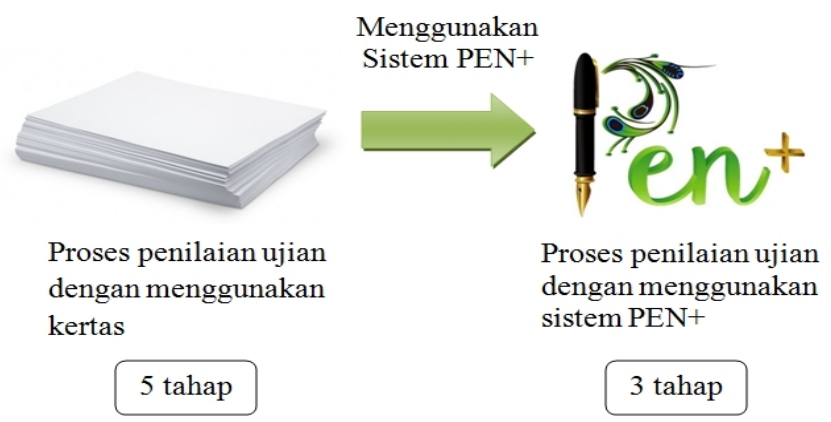

Gambar 1. Transformasi Penilaian

Berdasarkan Gambar 1, dijelaskan suatu transformasi mengenai proses penilaian ujian. Dengan digunakannya sistem Pen+ (Penilaian Plus), sistem penilaian yang konvensional dapat diubah menjadi online. Dengan diterapkannya sistem Pen+ (Penilaian Plus), dosen dapat dengan mudah melakukan proses input nilai, dan mahasiswa dapat mengetahui hasil nilai ujian dengan praktis melalui komputer atau smartphone, yang disajikan dalam bentuk tabel-tabel yang tersusun secara terurut berdasarkan NIM (Nomor Induk Mahasiswa). Sehingga dapat memberikan efek positif dalam peningkatan performa perkuliahan (Rahardja, 2017). Diharapkan dengan adanya sistem Pen+ (Penilaian Plus), dapat meminimalisir kendalakendala yang terjadi dalam proses penilaian pada Perguruan Tinggi Raharja.

\section{METODE}

Ketika merancang sistem, terdapat beberapa hal yang perlu diperhatikan agar kekurangan dan masalah yang terdapat pada sistem dapat ditangani. Dalam penelitian kali ini, metode yang terdiri dari 7 (tujuh) langkah digunakan oleh penulis, yang dapat dilihat pada Gambar 2(Rahardja, 2017).

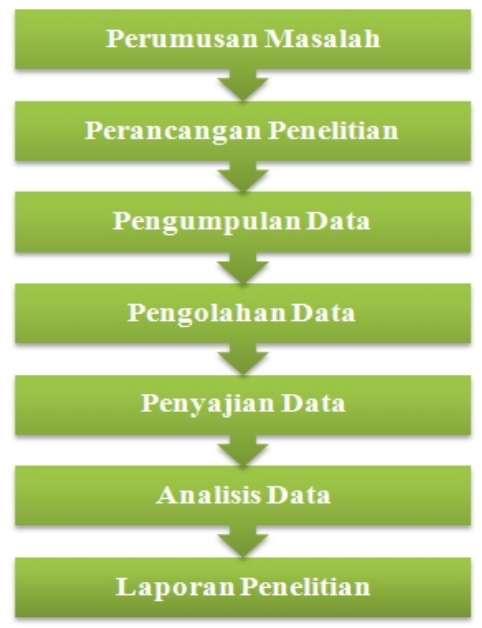

Gambar 2. Metode Penelitian 
Keterangan:

1. Perumusan masalah: observasi dilakukan terhadap sistem, dengan demikian kekurangan atau permasalahan yang terdapat pada sistem sebelumnya dapat diketahui, untuk selanjutnya dikembangkan menjadi sistem yang lebih baik dan mutakhir.

2. Perancangan penelitian: konsep sistem Pen+ (Penilaian Plus) dirancang ke dalam bentuk prototype. Perancangan ke dalam bentuk prototype ini dimaksudkan untuk memudahkan pemahaman peneliti mengenai sistem ketika sistem akan diterapkan ke dalam website, yang akan diakses oleh dosen dan mahasiswa.

3. Pengumpulan data: dibutuhkan beberapa data sebagai sumber informasi dalam proses perancangan sistem Pen+ (Penilaian Plus). Karenanya data-data yang diperlukan harus dicari dan dikumpulkan, seperti data kepala jurusan, data dosen pengampu mata kuliah, data mata kuliah, data mahasiswa dan data nilai ujian yaitu UTS (Ujian Tengah Semester), UAS (Ujian Akhir Semester) dan TM (Tugas Mandiri). Data-data yang telah terkumpul selanjutnya akan disimpan ke dalam database sistem Pen+ (Penilaian Plus).

4. Pengolahan data : Data-data yang terdapat pada database selanjutnya diintegrasikan. Website Pen+ (Penilaian Plus) menggunakan Yii Framework, yang merupakan kerangka kerja PHP, yang berbasis komponen-komponen kinerja dalam pengembangan sistem atau aplikasi.

5. Penyajian data: data yang telah diolah selanjutnya akan disajikan kepada end-user, yaitu kepala jurusan, RPU (Registrasi Perkuliahan Umum), mahasiswa dan dosen pengampu mata kuliah. Disajikan dalam bentuk grafik sebagai informasi yang mudah untuk dimengerti, serta berguna untuk dijadikan sebagai dasar pengambilan keputusan yang terpercaya.

6. Analisis data: hasil dari metode pertama, perumusan masalah, hingga metode selanjutnya akan dideskripsi dan dianalisa. Proses analisis data dilakukan untuk mendapatkan informasi mengenai hal-hal apa saja yang menjadi penyebab dari masalah yang terdapat pada sistem, sehingga kesimpulan dapat ditentukan.

7. Laporan penelitian: langkah terakhir yang dilakukan adalah membuat laporan penelitian dalam bentuk dokumen. Seluruh hasil penelitian yang telah didapatkan akan dilaporkan dengan rinci dan mendetail, sehingga pada akhirnya akan didapatkan penyelesaian yang baik dan tepat dari permasalahan yang dihadapi.

Selain menggunakan metode penelitian yang terdapat pada Gambar 2, studi literatur juga dilakukan penulis untuk menunjang metode sebelumnya. Berikut adalah 10 (sepuluh) literatur ilmiah yang digunakan sebagai sumber dalam penelitian ini:

1. Penelitian yang dilakukan oleh Diah Aryani, Qurotul Aini dan Fernanda Setyobudi Armansyah dengan judul "Perancangan Android Package Mobile Web pada Sistem Penilaian di Perguruan Tinggi" yang diteliti pada tahun 2017. Penelitian ini membahas Android Packaging Pen+ (Penilaian Plus) yang berfungsi untuk membantu dosen dan mahasiswa dalam proses penilaian perkuliahan pada Perguruan Tinggi Raharja (Aryani, 2017).

2. Penelitian yang dilakukan oleh Diah Aryani, Qurotul Aini dan Tasya Novelia pada tahun 2017 dengan judul "Perancangan PEN+ Menggunakan Metode YII Framework pada Perguruan Tinggi Raharja”. Dalam penelitian ini peneliti membahas mengenai penerapan sistem penilaian online pada Perguruan Tinggi Raharja yaitu sistem Pen+ (Penilaian Plus) yang berbasis YII framework (Aryani, 2017).

3. Penelitian yang dilakukan oleh Untung Rahardja, Indri Handayani dan Lilis Setiani dengan judul "Viewboard sebagai Laporan Jumlah Keseluruhan Artikel pada iLearning Raharja Ask and News", penelitian ini dilakukan pada tahun 2017. Membahas mengenai pemanfaatan viewboard pada iRAN (iLearning Raharja Ask and News) sebagai media informasi umum ataupun khusus pada Perguruan Tinggi Raharja (Rahardja, 2017).

4. Penelitian yang dilakukan oleh Untung Rahardja, Khanna Tiara dan Maya Ima Erviani pada tahun 2016 dengan judul "Optimalisasi Viewboard RhjFox Berbasis Bootstrap sebagai Sistem Penunjang Keputusan”. Penelitian ini membahas mengenai pemanfaatan RhjFox (Raharja Fox) sebagai forum online resmi penyedia informasi pada Perguruan Tinggi Raharja (Rahardja, 2016).

5. Penelitian yang dilakukan oleh Untung Rahardja, Deddy Pratama dan Ely Susanti dengan judul "Implementasi Viewboard dalam Mendukung Penyebaran Informasi dengan Penyajian Artificial Informatics pada Perguruan Tinggi" yang diteliti pada tahun 2016. Penelitian ini membahas penerapan Viewboard pada Perguruan Tinggi Raharja untuk mengukur statistik overview kemahasiswaan (Rahardja, 2016). 
6. Penelitian yang dilakukan oleh Sari Susanti, Erfian Junianto dan Rizal Rachman pada tahun 2017 dengan judul "Implementasi Framework Laravel pada Aplikasi Pengolah Nilai Akademik Berbasis Web”. Penelitian ini mengenai proses penginputan nilai rapor di SMK MVP ARS Internasional. Aplikasi web membantu proses pengolahan data dan informasi, sehingga nilai rapor menjadi lebih akurat dan cepat, keamanan data juga akan terjamin karena penyimpanan sudah terintegrasi dengan database (Susanti, 2017).

7. Penelitian yang dilakukan oleh Untung Rahardja, Qurotul Aini dan Neng Enay dengan judul "Optimalisasi Dashboard pada Sistem Penilaian Ujian Mahasiswa sebagai Media Informasi Perguruan Tinggi" yang diteliti pada tahun 2017. Penelitian ini membahas penggunaan sistem penilaian online Pen+ (Penilaian Plus) pada Perguruan Tinggi Raharja, yang dapat digunakan dosen untuk menginput nilai setiap mahasiswa secara online (Rahardja, 2017).

8. Penelitian yang dilakukan oleh Prihatin Oktivasari dan Zufar Fathi Suhardi pada tahun 2016 dengan judul "Pengembangan Fitur Downtime Reporting dan Modul Summary pada Sistem Monitor dan Pelaporan Operasional Mesin eCRM". Dalam penelitian ini peneliti mengembangkan aplikasi yang dapat memantau mesin eCRM (Cash Recycling Machine) secara mendetail. Pada tampilan sistem, digunakan graphic barHighcharts yang interaktif untuk menunjukkan detail data(Oktivasari, 2016).

9. Penelitian yang dilakukan oleh Chanchai Supaartagorn dengan judul "A Framework for Web-based Data Visualization Using Google Charts Based on MVC Pattern" yang diteliti pada tahun 2016. Penelitian ini mengenai pentingnya penyajian data dalam organisasi, salah satu cara penyajian data yang baik adalah dengan menggunakan Google Charts. Data yang tadinya masih terlihat biasa saja atau bahkan monoton, akan terlihat menjadi lebih menarik dan mudah dimengerti (Supaartagorn, 2016).

10. Penelitian yang dilakukan oleh Hussain Abo Surrah dan Fardus Saeed pada tahun 2014 dengan judul "The Importance of Using Google API Chart as a Content of QR Code". Penelitian ini membahas mengenai penerapan Google API Chart pada $Q R$ code yang biasa digunakan untuk menyampaikan informasi (Surrah, 2014).

Berdasarkan sepuluh (10) literatur ilmiah yang diteliti, dapat disimpulkan bahwa saat ini belum ada penelitian secara khusus mengenai viewboard berbasis interaktif Javascript charts pada sistem penilaian perguruan tinggi.

\section{HASIL DAN PEMBAHASAN}

\subsection{Analisa Permasalahan}

Demi kelancaran dan kemajuan proses perkuliahan, Perguruan Tinggi Raharja telah banyak berinovasi di berbagai bidang IT. Namun, masih terdapat beberapa permasalahan yang harus diatasi demi mendukung kegiatan akademik. Terdapat 5 (lima) permasalahan dalam penyajian informasi hasil nilai ujian dari dosen pengampu mata kuliah kepada mahasiswa.Permasalahan pertama adalah, sistem yang digunakan pada proses penilaian yang digunakan staff RPU (Registrasi Perkuliahan Umum) dalam melakukaninput nilai dari dosen masih menggunakan Microsoft Excel. Permasalahan yang kedua yaitu, dosen diberikan batas waktu input nilai selama 3 (tiga) hari setelah ujian dilaksanakan. Diharapkan dosen melakukan input nilai secara tepat waktu, namun pada kenyataannya masih ada dosen yang terlambat. Permasalahan yang ketiga adalah, kemungkinan terjadinya human error cukup tinggi dikarenakan dalam proses input data penilaian diperlukan ketelitian, agar kesalahan dapat dihindari. Permasalahan yang keempat adalah, terbuangnya banyak waktu dikarenakan dosen harus menyerahkan hasil nilai ujian yang telah dikoreksinya kepada staff RPU (Registrasi Perkuliahan Umum), kemudian staff RPU (Registrasi Perkuliahan Umum) akan memasukkan hasil nilai ujian dengan menggunakan Microsoft Excel, setelah itu hasil nilai ujiannya dicetak dan diserahkan kepada staff resepsionis untuk akhirnya ditempel di mading (majalah dinding), sehingga mahasiswa dapat mengetahui informasi perihal hasil nilai ujian namun tidak dapat diketahui secara online dimanapun dan kapanpun (Untung, 1978). Dan permasalahan yang terakhir yaitu yang kelima adalah, setelah diterapkannya sistem Pen+ (Penilaian Plus) informasi perihal penilaian dapat tersampaikan dengan baik, namun masih kurang efektif dikarenakan data-data yang disajikan masih dalam bentuk tabel. 


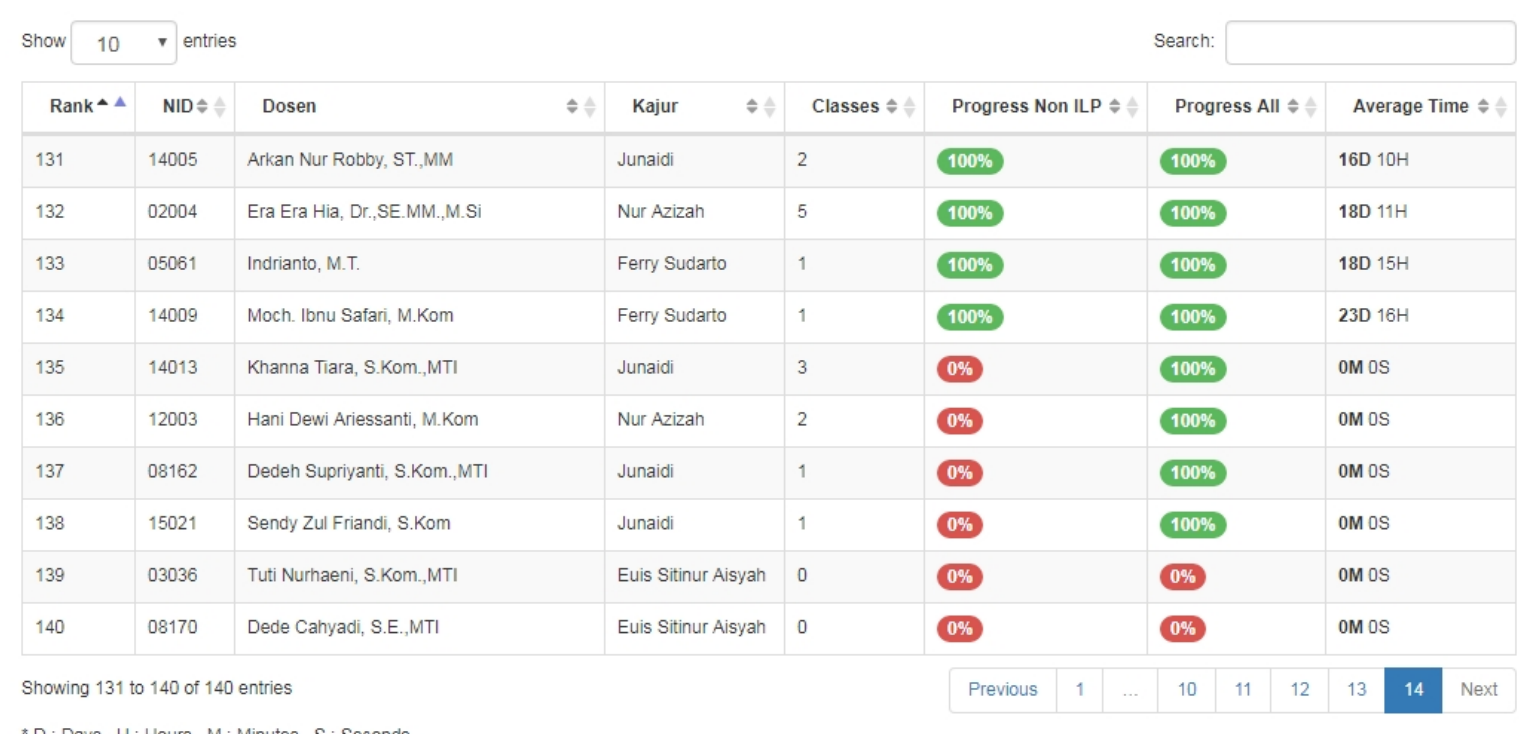

Gambar 3. Daftar Dosen dalam Tabel pada Website Pen+

Gambar di atas adalah tampilan dari sebuah tabel pada website Pen+ (Penilaian Plus), lebih tepatnya pada bagian viewboard dosen. Pada tabel daftar dosen terdapat 8 (delapan) kolom yaitu Rank, NID, Dosen, Kajur, Classes, Progress Non ILP, Progress All dan Average Time. Berdasarkan tabel daftar dosen juga dapat diketahui nama-nama dosen yang melakukan input nilai secara tepat waktu, yang ditandai dengan angka persentase berwarna hijau, dan juga dosen yang melakukan input nilai secara terlambat, yang ditandai dengan angka persentase berwarna merah.

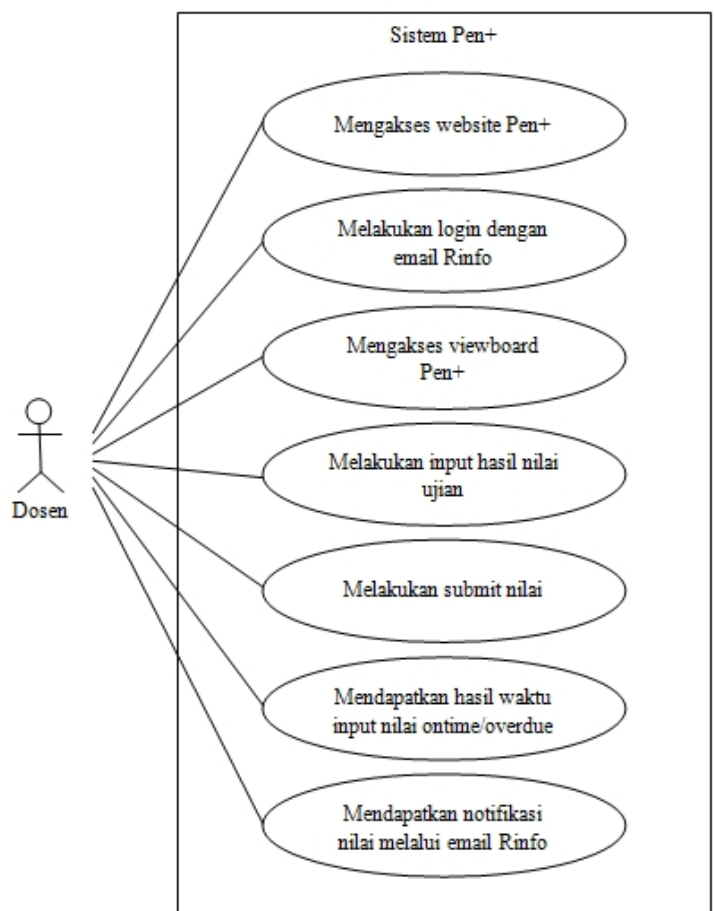

Gambar 4.Usecase Diagram InputNilai oleh Dosen dengan Menggunakan Sistem Pen+

Gambar di atas menjelaskan mengenai 7 (tujuh) langkah proses penginputan nilai hasil ujian, yang dilakukan oleh dosen pengampu mata kuliah pada Perguruan Tinggi Raharja dengan menggunakan sistem Pen+ (Penilaian Plus), yaitu: (1) Dosen mengakses website Pen+ (Penilaian Plus). (2) Dosen melakukan login pada sistem Pen+ (Penilaian Plus) dengan menggunakan email Rinfo. (3) Dosen mengakses viewboard Pen+ (Penilaian Plus). (4) Dosen melakukan input hasil nilai ujian yang telah dikoreksinya, seperti nilai UTS (Ujian Tengah Semester), UAS (Ujian Akhir Semester) dan TM (Tugas Mandiri). (5) Dosen memeriksa ulang nilai-nilai ujian yang telah dimasukkannya, lalu setelah yakin, nilai-nilai tersebut akan dosen submit. 
(6) Dosen mendapatkan informasi perihal hasil waktu input nilai yang dilakukannya, terdapat 2 (dua) hasil yaitu input nilai secara tepat waktu atau terlambat. (7) Dosen mendapatkan notifikasi melalui email Rinfo bahwa telah melakukan input hasil nilai ujian.

Dapat ditarik kesimpulan bahwa proses penyampaian informasi yang disajikan dalam Pen+ (Penilaian Plus) memang sudah terkomputerisasi, namun masih kurang efektif karena berdasarkan dari gambar 3 , gambar 4 dan penjelasan di atas, terbukti bahwa kekurangan yang terdapat pada sistem Pen+ (Penilaian Plus) salah satunya adalah penyajian informasi yang diterapkan masih menggunakan tabel, mengakibatkan sulitnya mahasiswa, kepala jurusan maupun dosen pengampu mata kuliah dalam mengolah informasi yang diberikan.

Untuk menangani permasalahan berdasarkan dari penjelasan di atas, maka demi proses penyampaian informasi yang cepat, efisien dan memberikan pelayanan yang baik kepada seluruh civitas Perguruan Tinggi Raharja, diperlukan sebuah media penyampaian media informasi yang lebih memberikan kemudahan daripada tabel, yaitu diagram atau grafik, yang dapat menyajikan data dengan lebih ringkas dan efektif, sehingga memudahkan end-user dalam mengambil keputusan.

\subsection{Rancangan Program}

Dalam mengatasi permasalahan penyajian data yang masih kurang efektif pada sistem Pen+ (Penilaian Plus), maka perlu diatasi dengan diterapkannya grafik Highcharts dan Google Charts, sehingga data yang disajikan dapat dimengerti dengan lebih baik.

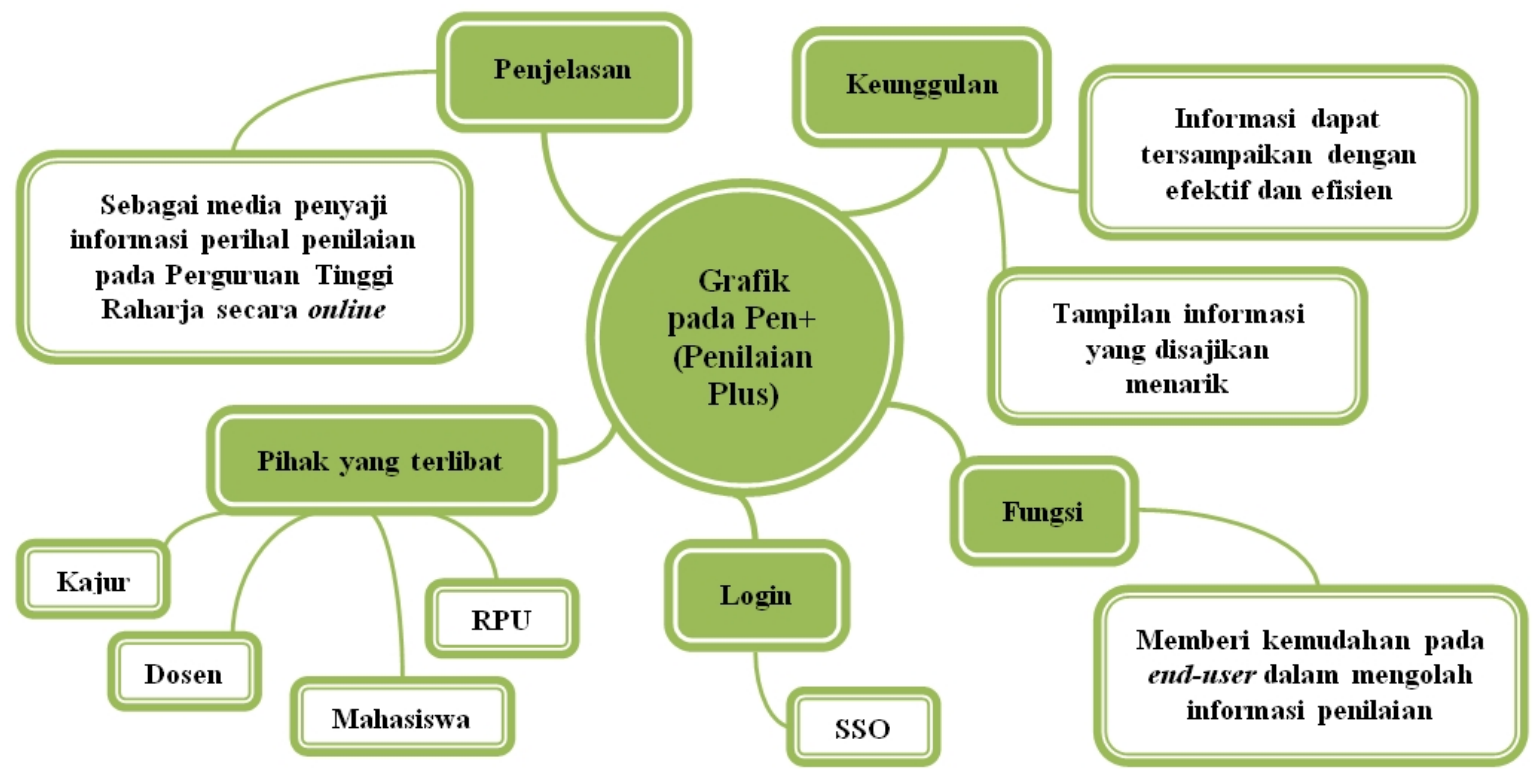

Gambar 5. Mind Map Grafik pada Pen+

Gambar di atas merupakan tampilan dari mind map yang menjelaskan tentang grafik pada Pen+ (Penilaian Plus), yang terdiri dari: (1) Penjelasan: sebagai media penyaji informasi perihal penilaian pada Perguruan Tinggi Raharja secara online. (2) Keunggulan: informasi dapat tersampaikan dengan efektif dan efisien, serta tampilan informasi yang disajikan menarik. (3) Fungsi: memberi kemudahan pada end-user dalam mengolah informasi penilaian. (4) Login: SSO (SingleSign On/Out) menggunakan email Rinfo. (5) Pihak yang terlibat: kepala jurusan, dosen, mahasiswa dan RPU (Registrasi Perkuliahan Umum).

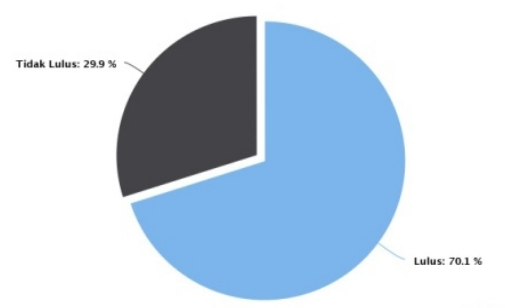

Gambar 6. Prototype Grafik Highcharts 
Highcharts adalah library charting yang mudah digunakan untuk menyajikan data berupa grafik interaktif ke dalam suatu website. Grafik Highcharts terlihat rapi dan indah, juga bekerja dengan cepat. Selain itu Highcharts juga sesuai untuk digunakan di berbagai browser(Song, 2016). Pada prototype gambar 6, digunakan grafik pie mengenai persentase mahasiswa, yang lulus sebanyak $70,1 \%$ dan yang tidak lulus sebanyak $29,9 \%$.

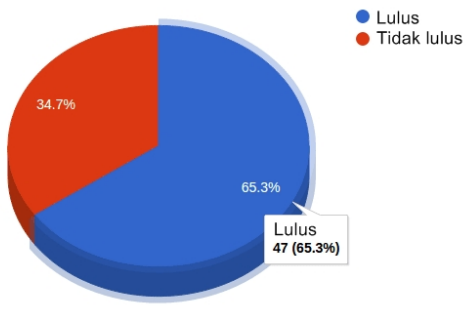

Gambar 7. Prototype Grafik Google Charts

Google Charts merupakan media penyaji data ke dalam bentuk grafik yang mendasar dan sederhana, yang digunakan untuk memvisualisasikan data. Selain itu Google Charts juga memiliki banyak kelebihan seperti up-to-date, fleksibel, stabil, dan serba guna (Supaartagorn, 2016). Prototype grafik pieGoogle Charts yang terdapat pada gambar 7 menjelaskan tentang presentase mahasiswa, sebanyak $65,3 \%$ lulus dan sebanyak $34,7 \%$ tidak lulus.

\subsection{Flowchatrt Algoritma}

Setelah meneliti permasalahan yang terjadi pada sistem penilaian online yang berjalan, maka alur proses melihat hasil nilai ujian dengan menggunakan Pen+ (Penilaian Plus) yang dilakukan oleh end-user seperti yang digambarkan pada flowchart berikut ini :

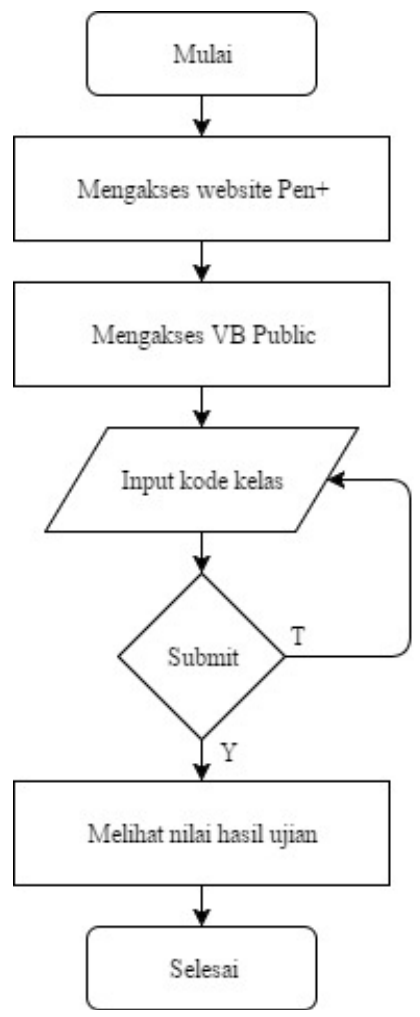

Gambar 8. Flowchart Melihat Nilai Hasil Ujian

Gambar di atas menjelaskan 5 (lima) langkah proses melihat hasil nilai ujian pada Perguruan Tinggi Raharja secara online dengan menggunakan sistem Pen+ (Penilaian Plus), yaitu sebagai berikut: (1) End-user mengakses website Pen+ (Penilaian Plus) pada http://penplus.raharja.ac.id. (2) End-user mengakses halaman VB Public. (3) End-user melakukan input kode kelas dari mata kuliah yang nilai ujiannya ingin dilihat. 
(4)End-user melakukan submit kode kelas. (5) Sistem Pen+ (Penilaian Plus) akan menampilkan informasi perihal hasil nilai ujian pada kode kelas yang telah dilakukan input.

\subsection{Listing Program}

Berikut ini adalahlisting program yang digunakan pada grafik Highchartsdalam sistem Pen+ (Penilaian Plus):

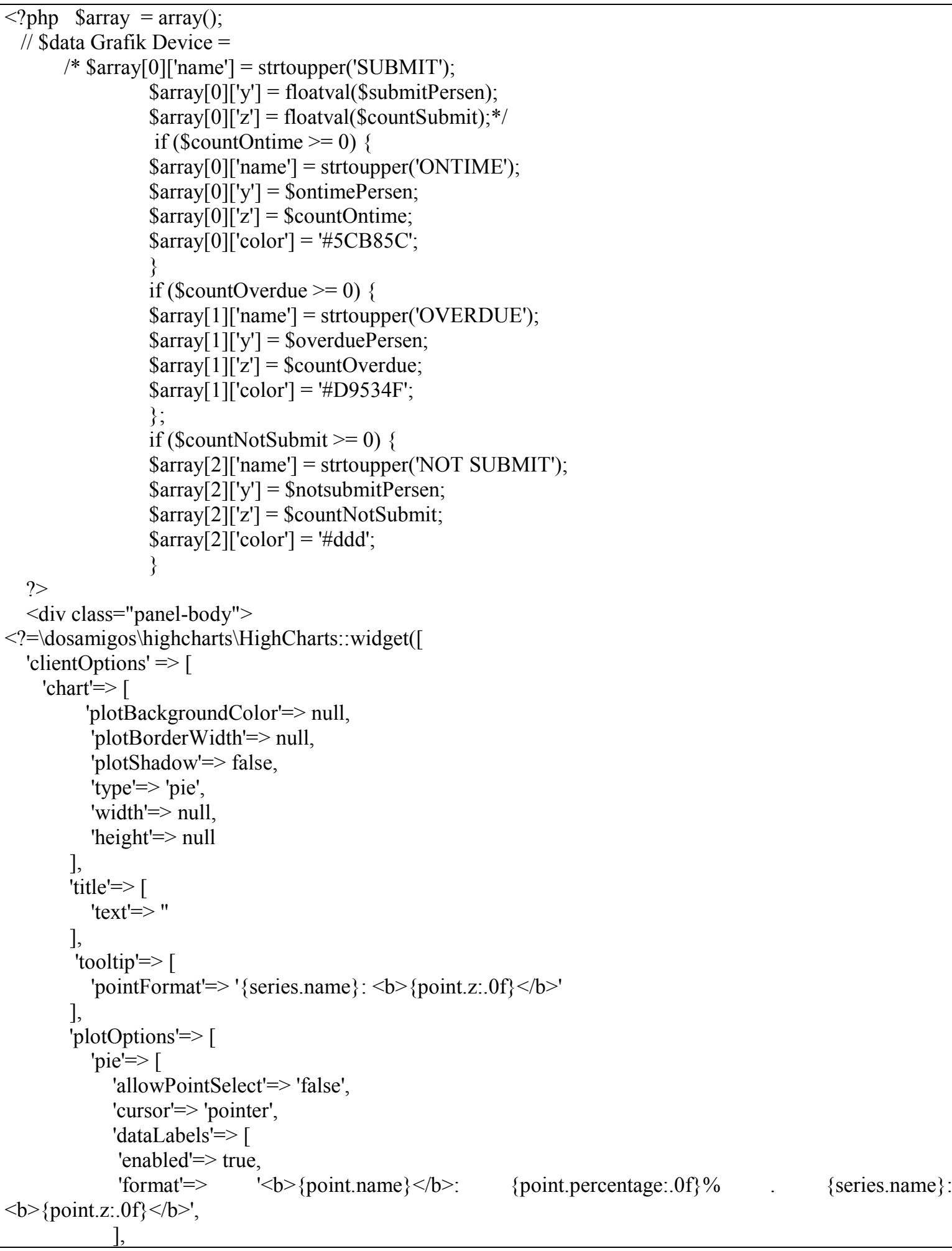




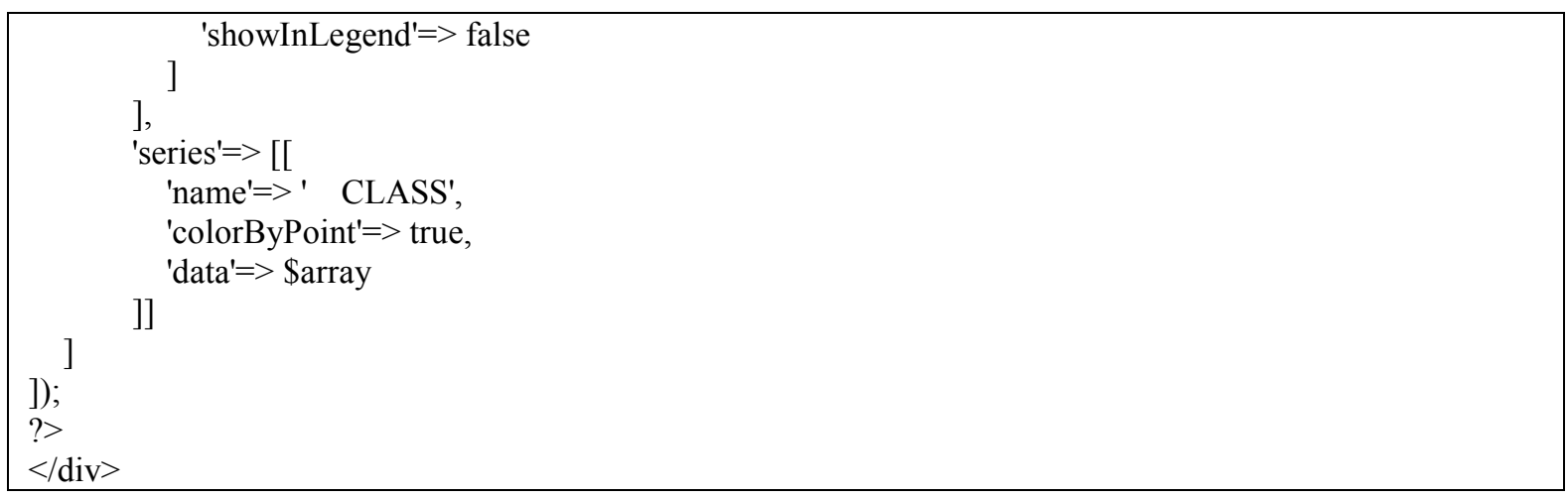

\subsection{Implementasi}

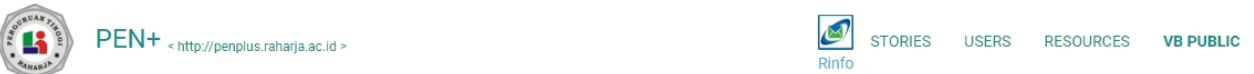

\section{WELCOME TO THE MAGICAL}

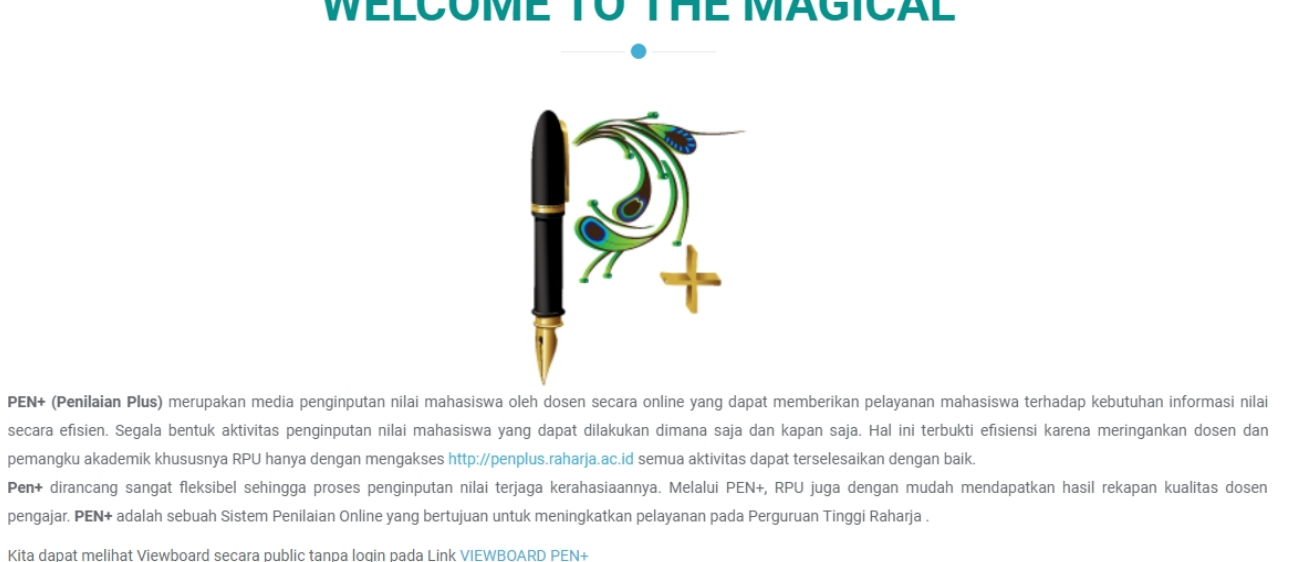

Gambar 9. Halaman Utama Pen+ (Penilaian Plus)

Gambar 9 merupakan interface halaman utama dari website Pen+ (Penilaian Plus). Menu yang ditampilakn yaitu stories, users, resources, dan VB public. Pada menu stories menampilkan informasi mengenai penjelasan Pen+ (Penilaian Plus), menu users menampilkan informasi mengenai siapa saja pengguna Pen+ (Penilaian Plus), menu resources menampilkan informasi mengenai cara menggunakan Pen+ (Penilaian Plus) dan menu VB public menampilkan informasi mengenai hasil nilai ujian.

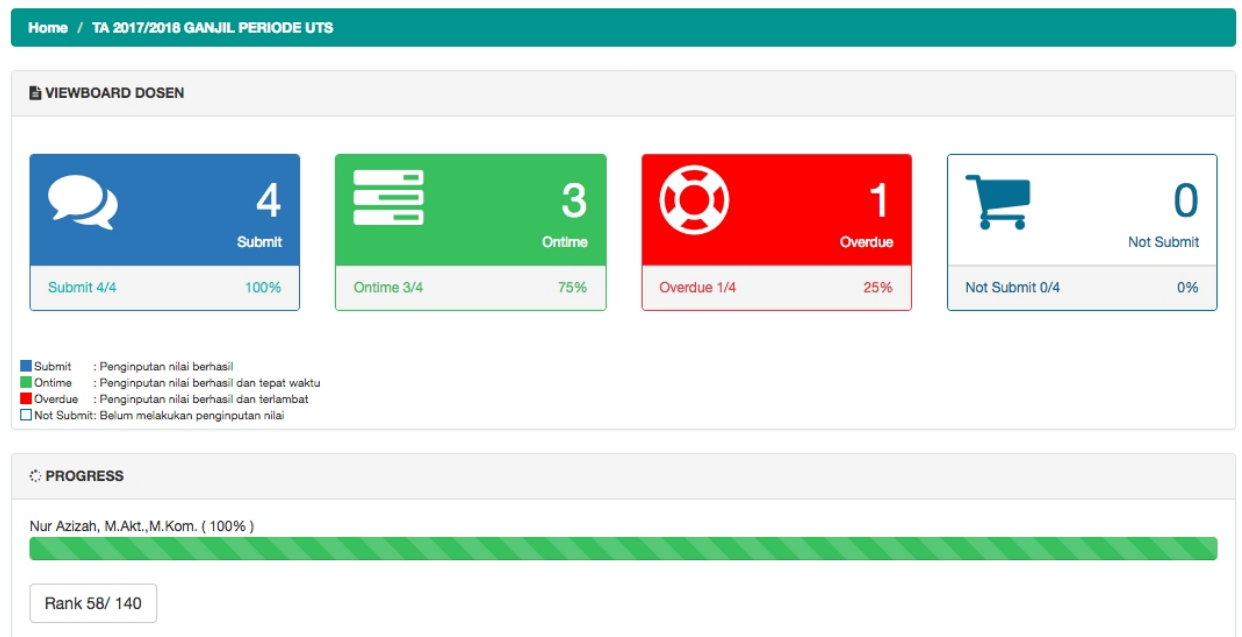

Gambar 10. Proses Input Nilai 
Pada gambar 10 ditampilkan informasi mengenai dosen bernama Nur Azizah, M.Akt., M.Kom. yang telah melakukan input nilai dari seluruh kelas yang diajarnya, dengan total kelas sebanyak 4 kelas dan keterangannya adalah 3 kelas di input secara tepat waktu (ontime) dan 1 kelas secara terlambat (overdue).

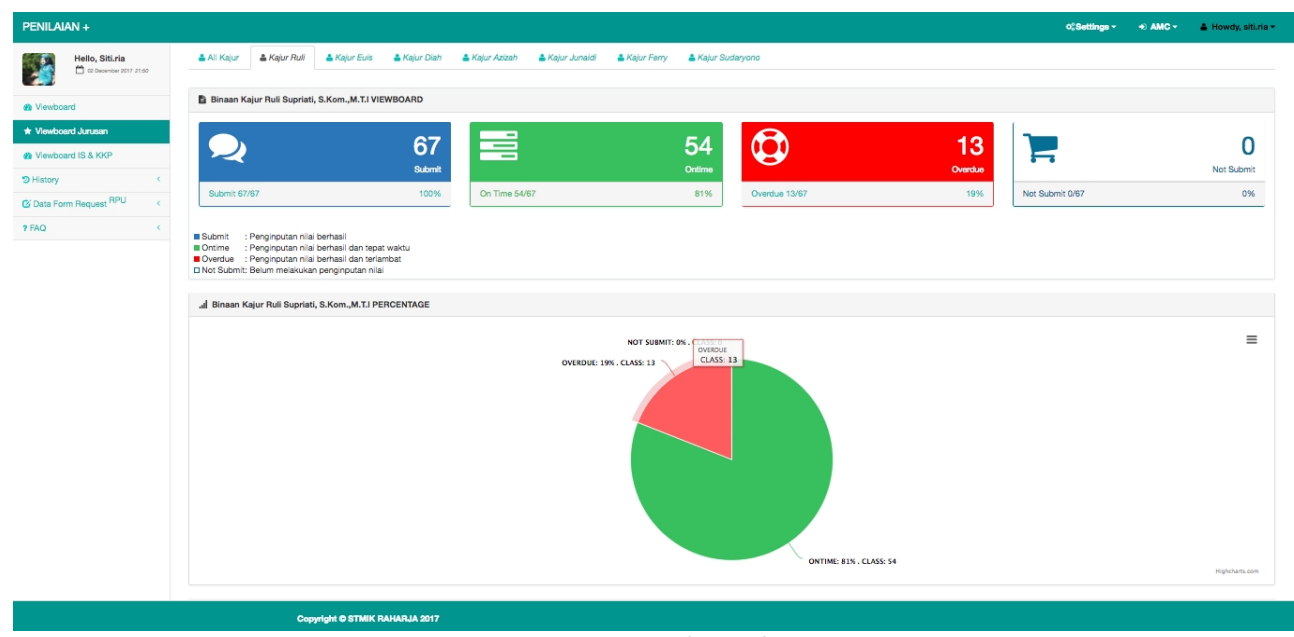

Gambar 11. Viewboard Jurusan

Kepala jurusan yang membina beberapa dosen dapat mengetahui informasi perihal progress input nilai yang telah dilakukan para dosen binaannya. Grafik pieHighcharts digunakan untuk menampilkan informasi tersebut, yang disajikan pada viewboard jurusan. Gambar 11 menampilan informasi mengenai kepala jurusan bernama Ruli Supriati, S.Kom., M.T.I dengan keterangan para dosen pengampu mata kuliah binaannya telah melakukan input nilai sebanyak 67 kelas, dengan keterangan 54 kelas secara tepat waktu (ontime) dan 13 kelas secara terlambat (overdue).

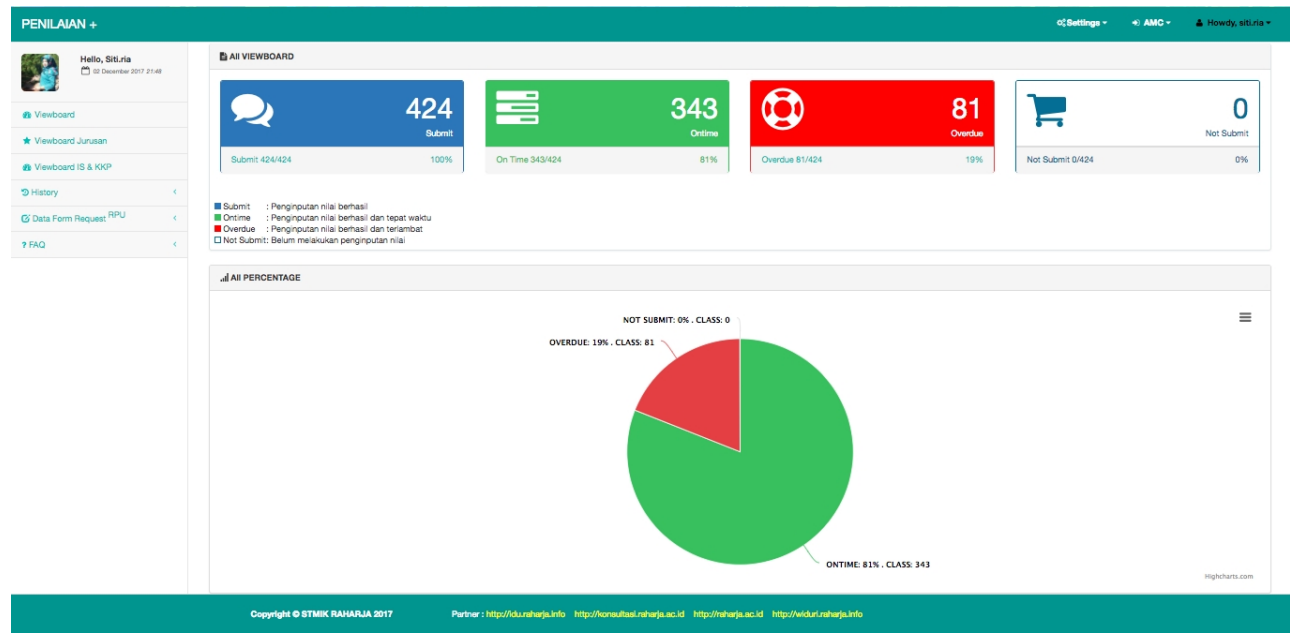

Gambar 12.Viewboard Keseluruhan

Berdasarkan gambar 12, ditampilkan informasi yang disajikan dalam bentuk grafik pieHighcharts, mengenai keseluruhan dari total kelas yang telah dilakukan input nilai oleh dosen pengampu mata kuliah yaitu sebanyak 424 kelas, dengan keterangan 343 kelas telah dilakukan input nilai secara tepat waktu (ontime) dan 81 kelas secara terlambat (overdue). 


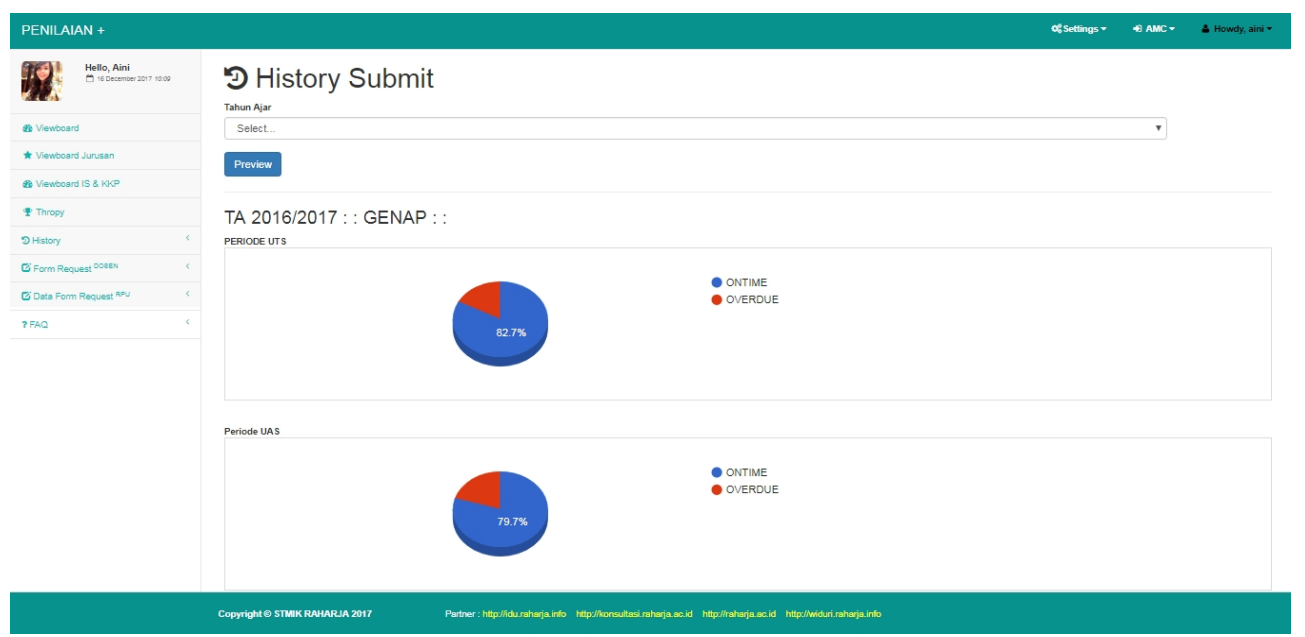

Gambar 13.History Submit

Pada gambar 13 ditampilkan informasi yang disajikan ke dalam bentuk grafik pieGoogle Charts mengenai input nilai dosen pada tahun ajaran genap 2016/2017. Terdapat grafik periode Ujian Tengah Semester (UTS) dengan keterangan input nilai dilakukan secara tepat waktu (ontime) sebanyak $82,7 \%$ dan sisanya $\mathbf{1 7 , 3 \%}$ secara terlambat (overdue), lalu grafik periode Ujian Akhir Semester (UAS) dengan keterangan $79,7 \%$ input nilai secara tepat waktu (ontime) dan $20,3 \%$ secara terlambat (overdue).

\section{PENUTUP}

\subsection{Kesimpulan}

Dari sistem yang telah dibuat maka dapat ditarik 5 (lima) kesimpulan, bahwa dengan adanya sistem Pen+ (Penilaian Plus) yang disertai grafik Highcharts dan Google Charts, dapat memberikan kemajuan dalam proses perkuliahan, yaitu:

1. Proses penilaian yang diterapkan menjadi lebih efektif dan efisien, karena memudahkan pihak dosen, RPU (Registrasi Perkuliahan Umum), kepala jurusan dan mahasiswa.

2. Proses input nilai yang dilakukan dosen dapat terekap dan terdokumentasi dengan baik. Hal ini terbukti dari informasi yang disajikan pada grafik pie Highcharts dan Google Charts yang meringkas keseluruhan kinerja dosen.

3. Human error dapat diminimalisir, karena proses input nilai dengan Pen+ (Penilaian Plus) tidak memerlukan ketelitian tinggi seperti saat melakukan input nilai dengan menggunakan Microsoft Excel.

4. Waktu yang dibutuhkan dari awal proses input nilai sampai disajikan kepada end-user menjadi lebih cepat.

5. Dengan adanya grafik pieHighcharts dan Google Charts yang penuh dengan warna dan up-to-date pada website Pen+ (Penilaian Plus), informasi yang disajikan menjadi lebih menarik dan ringkas, sehingga dapat dijadikan sebagai dasar untuk mengambil keputusan yang tepat.

\subsection{Saran}

Terdapat 3 (tiga) saran yang direkomendasikan oleh penulis berdasarkan dari pembahasan yang telah diuraikan sebelumnya, sehingga dapat berguna untuk perancangan program ini, yaitu:

1. Diperlukan pengembangan dalam penggunaan grafik supaya tidak hanya menampilkan informasi mengenai kinerja dosen pengampu mata kuliah saja.

2. Viewboard pada sistem Pen+ (Penilaian Plus) dapat lebih diperluas agar dapat memberikan informasi dengan performa yang lebih lengkap dan mendetail.

3. Penggunaan grafik pada sistem penilaian dapat digunakan pada seluruh perguruan tinggi demi menunjang kinerja proses perkuliahan. 


\section{DAFTAR RUJUKAN}

Aini, Q. (2016). Pengembangan PEN+ (Penilaian Plus) untuk Efisiensi RPU dalam Rangka Meningkatkan Tingkat Kepuasan (Thesis report majoring in Teknik Informatika, STMIK Raharja, Kota Tangerang, Indonesia).

Aryani, D., Aini, Q., \& Armansyah, F. S. (2017). Perancangan Android Package Mobile Web pada Sistem Penilaian di Perguruan Tinggi. SISFOTENIKA, 7(2), 155-166.

Aryani, D., Aini, Q., \& Novelia, T. (2017). Perancangan Pen+ Menggunakan Metode YII Framework pada Perguruan Tinggi Raharja. SENSI Journal, 3(1), 48-63.

Kuntoro, P. T., Untung, R., \& Siti, C. (1978). Pengontrolan Mutu Sistem Informasi Dengan Metode Database Self Monitoring. CCIT Journal ISSN, 8282.

Oktivasari, P., \& Suhardi, Z. F. (2016). Pengembangan Fitur Downtime Reporting Dan Modul Summary Pada Sistem Monitor Dan Pelaporan Operasional Mesin Ecrm. JURNAL TEKNIK INFORMATIKA, 9(1).

Rahardja, U., Aini, Q., \& Enay, N. (2017). Optimalisasi Dashboard pada Sistem Penilaian Sebagai Media Informasi di Perguruan Tinggi. SISFOTENIKA, 7(2), 167-176.

Rahardja, U., Aini, Q., \& Khoirunisa, A. (2017). Implementasi Business Intelligence Menggunakan Highchart pada Sistem Penilaian Absensi berbasis YII Framework. CSRID (Computer Science Research and Its Development Journal), 9(2), 115-124.

Rahardja, U., Handayani, I., \& Setiani, L. (2017). Viewboard Sebagai Laporan Jumlah Keseluruhan Artikel Pada iLearning Raharja Ask and News. CogITo Smart Journal, 3(1), 42-55.

Rahardja, U., \& Nurdin, I. (2014). Implementasi iMe (iLearning Media) Dalam Mendukung Sistem Pembelajaran iLearning Pada Perguruan Tinggi. CCIT Journal, 8(1), 167-182.

Rahardja, U., Pratama, D., \& Susanti, E. (2016). Implementasi Viewboard Dalam Mendukung Penyebaran Informasi Dengan Penyajian Artificial Informatics Pada Perguruan Tinggi. CCIT Journal, 9(03), 251257.

Rahardja, U., Tejosuwito, N. J., \& Armansyah, F. S. (2017). PERANCANGAN APLIKASI PEN+ BERBASIS MOBILE UNTUK MEMUDAHKAN KINERJA DOSEN PADA PERGURUAN TINGGI. Technomedia Journal, 1(2), 51-62.

Rahardja, U., Tiara, K., \& Erviani, M. I. (2016). OPTIMALISASI VIEWBOARD RHJFOX BERBASIS BOOTSTRAP SEBAGAI SISTEM PENUNJANG KEPUTUSAN. Technomedia Journal, 1(1), 50-64.

Rahardja, U., Tiara, K., \& Wijaya, R. I. T. (2014). Penerapan Rinfo Sebagai Media Pendukung Untuk Proses Pembelajaran Pada Perguruan Tinggi Raharja. Jurnal CCIT, 8(1).

Sari, H. P., \& Muhartini, R. (2017). SISTEM APLIKASI PENGOLAHAN NILAI RAPORT SDN TANJUNGANOM 2 KECAMATAN TANJUNGANOM NGANJUK. ANTIVIRUS: Jurnal Ilmiah Teknik Informatika, 11(1).

Song, J. B., Song, J. H., Chai, J. P., \& Yang, Y. (2016). Data Visualization of the Advertising Exchange Flow Statements Generation System on Demand Side Platform Based on Highcharts. In MATEC Web of Conferences (Vol. 63, p. 05029). EDP Sciences.

Supaartagorn, C. (2016). A Framework for Web-based Data Visualization using Google charts based on MVC pattern. King Mongkut's University of Technology North Bangkok International Journal of Applied Science and Technology, 9(4).

Surrah, H. A. (2014). THE IMPORTANCE OF USING GOOGLE API CHART ASA CONTENT OF QR CODE. International Journal of Global Research in Computer Science (UGC Approved Journal), 3(2), 1-4.

Susanti, S., Junianto, E., \& Rachman, R. (2017). Implementasi Framework Laravel Pada Aplikasi Pengolah Nilai Akademik Berbasis Web. Jurnal Informatika, 4(1).

U, Rahardja., A. Moein., \& N. Lutfiani. (2017). Leadership, Competency, Working Motivation and Performance of High Private Education Lecturer with Institution Accreditation B: Area Kopertis IV Banten Province. Man In India. 97 (24), 179-192

Untung, R., Muhamad, Y., \& Eva, R. Optimalisasi Key Performance Indicators (KPI) Melalui Pendekatan Balance Scorecard Upaya Mengimplementasikan Performance Management System (PMS) Pada Perguruan Tinggi. CCIT Journal ISSN, 6(2).

Untung, R., Suryo, G., \& Valent, S. (1978). Access Restriction Sebagai Bentuk Pengamanan Dengan Metode IP Token. CCIT Journal ISSN, 8282.

Warsito, A. B., \& Yusup, M. (2014). Kajian Yii Framework dalam Pengembangan Website Perguruan Tinggi. CCIT Journal 3 (STMIK RAHARJA), 7(3), 437-451. 